\title{
A Review of the Research on the Competitiveness of China's Beverage
}

\section{Industry}

\author{
Yusong Xing ${ }^{1,} a^{*}$ and Yue Guo ${ }^{2, b}$ \\ ${ }^{1}$ College of Economy and Law, Bohai University, Jinzhou 121013, China \\ ${ }^{1}$ School of Accounting, Jilin University of Finance and Economics, Changchun, 130117, China \\ a2319771479@qq.com, b195269743@qq.com \\ *The corresponding author
}

Keywords: Industrial competitiveness; Beverage industry; Diamond model

\begin{abstract}
At present, there are many researches on the competitiveness of China's manufacturing industry, but there are few researches on the competitiveness of China's beverage industry, especially the inter-provincial competitiveness. Based on researches into domestic and foreign competitiveness theories, this paper analyzes the current development of China's beverage manufacturing industry, summarizes the researches into competitiveness of the beverage industry and combines the "diamond theory" to study the inter-provincial competitiveness of China's beverage competitiveness in different regions. Therefore, it is necessary to combine the actual situation to design an index system related to the system, find factors influencing the competitiveness, propose the advantages of competitiveness and the gap, and then propose measures and suggestions to improve the competitiveness.
\end{abstract}

\section{Introduction}

Manufacturing is an important pillar industry in the process of industrialization that promotes economic growth and development. Strongly competitive manufacturing can create a sustainable economy whose impact directly affects the position and the role of a country or region in the world economic landscape.

In 2013, the number of enterprises above designated size China's beverage industry was 5529; industrial sales output value was 151.496 billion yuan, an increase of $14.48 \%$ over 2012 ; total assets was $1,311.956$ billion yuan, an increase of $17.38 \%$ over 2012; main business income was 1532.737 billion yuan, an increase of $13.12 \%$ over 2012; total profit was 171.690 billion yuan, an increase of $7.15 \%$ over 2012; and the total number of employees in the beverage manufacturing industry was 1.5781 million. Among them, Liaoning Province achieved industrial sales output value of 47.912 billion yuan in 2013 in the beverage industry, total assets were 28.138 billion yuan, the main business income was 46.404 billion yuan, the total profit was 3.676 billion yuan, and 38,800 people worked in the beverage manufacturing industry. The study found that the productivity index of the beverage industry in Liaoning Province ranked among the top in the 30 provinces (except Tibet).

\section{Relevant Concepts and Theoretical Basis}

\section{Relevant Concepts}

Industrial Competitiveness

Michael Porter is the first foreign scholar to study the competitiveness of the industry at the industry level. He defined the industry competitiveness as "the ability of an industry to expand the market, occupy the market and obtain more profits than competitors under the certain conditions". ${ }^{[1]}$ He believes that the country is an important factor affecting the competitiveness of industry and enterprises, a country affects the competitiveness of the industry through "shaping the environment", and the national competitiveness is mainly embodied in the industrial competitiveness. Due to the 
different scope of competition, the industrial competitiveness can be divided into industrial international competitiveness and regional industrial competitiveness.

Jin Bei (1996) is the first domestic scholars studying competitiveness from the perspective of industrial development, and he believes that: industrial competitiveness, also known as the international competitiveness of the industry, refers to a country or a region's competitive capacity in a particular industry relative to other countries or regions in terms of production efficiency, meeting market demand, and gaining sustained profits ${ }^{[2]}$.

Beverage Industry

Beverage manufacturing industry, including alcohol manufacturing, wine manufacturing, soft drinks manufacturing, refined tea processing in four major industries and 13 sub-categories. The manufacture of beverages includes manufacturing of liquor, manufacturing of beer, manufacturing of beer, manufacturing of wine and other wines; manufacture of soft drinks includes manufacturing of carbonated beverages, manufacturing of pots (cans), manufacturing of fruit and vegetable juices and fruit and vegetable beverages, milk beverages and vegetable protein beverage manufacturing, solid beverage manufacturing and tea beverages and other soft drinks. The main products are liquor, beer, carbonated drinks, tea drinks and bottle (can) installed drinking water.

\section{The Theoretical Basis of Industrial Competitiveness}

Theory of Absolute Advantage

In 1776, Adam Smith proposed the theory of absolute advantage [3]. When a country has an absolute advantage over the production of a commodity relative to another country but has an absolute disadvantage in the production of another commodity, then the country should specialize in producing and exporting products that have an absolute advantage in the country, but import products with absolute disadvantage another country. Through the transaction, the two countries will benefit from it. Therefore, Smith advocates free trade and opposes trade protection policy through tariff or non-tariff barriers.

Theory of Comparative Advantage

In 1817, David Ricardo put forward the theory of comparative advantage ${ }^{[4]}$. A country does not have an absolute advantage even in the production of every commodity, but it still has a comparative advantage in the production of certain commodities; it not only has the absolute advantage among countries that can increase benefits through trade, and countries with a comparative advantage can also increase benefits through trade. According to the comparative advantage theory, countries with comparative advantages of goods are internationally competitive.

In 1936, Gottfried Von Haberler explained the source of comparative advantage with opportunity cost theory ${ }^{[5]}$. If a country has a lower chance of producing a commodity than other countries, it has a comparative advantage in the production of the commodity; and vice versa.

Factor Endowment Theory

In 1933, the Swedish economics Bertil Ohlin put forward the theory of factor endowment, which further revealed the source of comparative advantage. The difference of the relative price is the basis of the international trade. The reason of the price difference is that the factor endowment of different countries is different, and the factor endowment is the root cause of the international trade. The theory explains the comparative advantage from the production of elements and the price difference between the factors, that is, a country using low-cost production factors of production products are competitive.

Competitive Advantage Theory

In the 1980s and 1990s, Michael Porter published "Competitive Strategies: Analyze Industry and Competitor Technology", "Competition in the Global Industry", "Competitive Advantage: Creating and Maintaining Good Performance" and "National Competitive Advantage", revealing the "diamond model" of enterprises' competitive advantage, "five competitiveness roles" of industry's competitive advantages and the "corporate value chain" model revealing corporate competitiveness, and an international competitiveness theory system covering national, industrial and corporate competitiveness advantages has been formed. The national "diamond model" is composed of four basic elements and two auxiliary elements, and the specific structure was shown in Fig.1. 


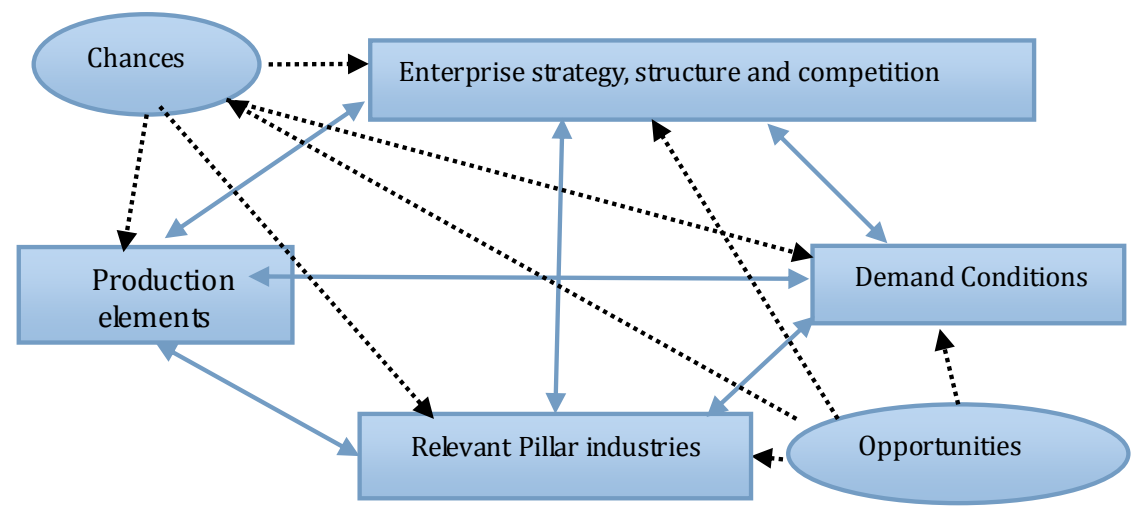

Figure 1. National "Diamond Model"

Following Porter, many scholars have supplemented and perfected the theory of competitive advantage. John Harry Dunning (1993) regards multinationals as a third exogenous variable added to the diamond model of Porter to build an "international diamond model" ${ }^{[6]}$. Krugman and Cruz (1998) built a "double diamond model" when studying Canadian international competitiveness, believing that Canada's industrial competitive advantage is not only due to Canada's own economic environment, but also closely related to the US economic environment, while the economic environment Will have an impact on the two countries. Moon et al. (1998) proposed a "generalized double diamond model" [7] in order to expand the competitiveness comparable to all small economies. Cho and Moon (2000) analyzed the "nine factor models" of South Korea's competitive advantage and the construction of Korean industrial competitiveness: material elements, human factors, business environment, domestic demand, related and support industries and external opportunities ${ }^{[8]}$.

These theories explain the source of competitiveness from different angles and different sides, and have obvious evolution of social and economic development, which reflects the process of deepening the exploration of competitiveness theory.

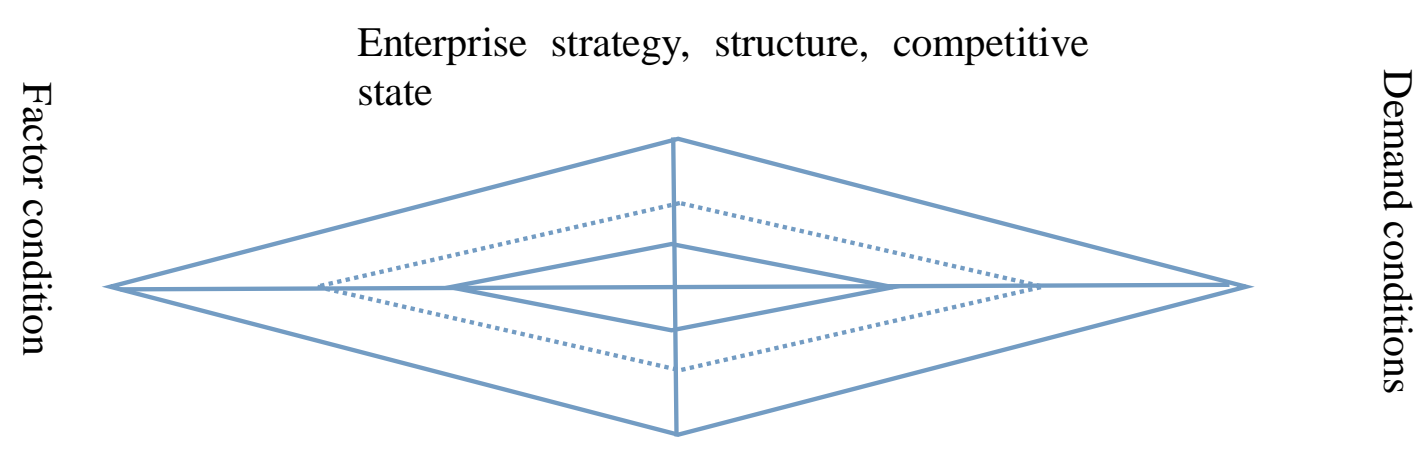

Relevant pillar industries

Figure 2. Double-Diamond Model

\section{Current Status of China's Beverage Industry}

China's beverage industry is a new industry developed since the reform and opening up. After 30 years of development, the beverage manufacturing industry has gradually changed the scale, the product structure is single and the competition is disorderly. The scale and intensification of the beverage enterprises have been continuously improved, Product structure is becoming more reasonable. China's beverage industry in the development of significant results, the national brand has more than a dozen, five products in 22 brands were rated as Chinese famous brand. Over the past five years, China's beverage market has become one of the fastest growing markets in China's 
food industry, with Chinese drinks growing at a rate of $16 \%$ each year.

Chinese liquor is one of the world famous six distillation of wine, unique technology, has a long history, renowned Chinese and foreign. In 2013, the liquor industry achieved operating income of 501.8 billion yuan, profits of 80.49 billion yuan, production reached 12262037.42 thousand liters. In recent years, China's liquor industry to the relatively orderly competition to change, the brand trend is obvious, the distribution channels flat, dealers specialized; international capital, venture capital, industrial capital and so on have entered the liquor industry, capital mergers and acquisitions to implement a strategic layout.

China is the hometown of tea, there are six tea categories, twenty tea production provinces, 80 million tea farmers, is a veritable tea country. In 2011, China's tea garden area reached 2112.5 thousand hectares, the total output of tea reached 1.62 million tons, tea agricultural output value close to 72.9 billion yuan. In 2012, China's total output of dry hair tea $1,789,800$ tons, the total output value of 95.36 billion yuan. 2013 tea production of 1.93 million tons, an increase of $7.9 \%$, tea exports 294,100 tons, the amount of about 1.1 billion US dollars, up $3.04 \%$ over the previous year, respectively, $18.32 \%$. From the domestic point of view, tea has become an indispensable social health drinks and spiritual drinks; from the international demand, China's tea exports have maintained steady growth.

British Brand Finance announced the 2015 national brand of the world's top 500 enterprises, with 39 Chinese enterprises, mainly in the banking industry and information technology industry, accounting, totally 19 enterprises, China Guizhou Maotai Distillery (Group) Co., Ltd. ranked the $317^{\text {th }}$. Foreign beverage manufacturing companies to enter the world's top 500 enterprises in the United States 4, Australia, Britain, France, Netherlands, Japan, Brazil, Mexico each one. "China's top 500 enterprise development report 2014" on the efficiency of China's enterprises 200 good statistics, including beverage manufacturing a total of seven companies to enter: China Guizhou Maotai Distillery (Group) Co., Ltd. (ranked 35), Hangzhou Wahaha Group Co., Ltd. (Ranked 49), Hebei Yibin Wuliangye Group Co., Ltd. (Rank 59), Jiangsu Yanghe Distillery Co., Ltd. (Rank 71), Tsingtao Brewery Co., Ltd. (ranked 157), Hebei Yang Yuan Zhihui Beverage Co., Rank 184), Vivian Group Co., Ltd. (ranked 190). The world's top 500 industry in 2014, the main business profit margins of the top 10 industry statistics, wine manufacturing ranked third, the beverage processing industry ranked fifth, the world ranked fourth in the beverage manufacturing industry.

Beverage manufacturing industry is the most important part of the daily life in the manufacturing industry. China as a leader in emerging markets, its great potential by the countries around the world, as early as 1990s, foreign enterprises to accelerate the pace of mergers and acquisitions. Among them, Danone is most active, first with the Wahaha joint venture and shareholding of $41 \%$, after being acquired Shenzhen Yili, robust, Shanghai Meilin is, 2006 light and Huiyuan shares. After the acquisition of unity and cooperation Jianlibao and Jinmailang. By virtue of its strong financial strength and advanced management experience, the beverage enterprises of foreign investment have been able to buy domestic enterprises in horizontal or vertical direction. Local companies are also trying to buy, due to the limited funds of their own enterprises, from the local government is too large, and finally make these acquisitions nothing. Meanwhile, the acquisition of foreign brands is gradually fade out of the market. Based on this, China promulgated the "anti-monopoly law" in July 31, 2007, and with the implementation of the $\mathrm{L}$ in 2008 , the number of mergers and acquisitions in China's beverage industry and other industries have a legal basis for the. Since the anti-monopoly law was promulgated, the most interesting is the acquisition of Huiyuan Juice Coca Cola Co. In September 3, 2008, the Coca Cola Co announced the acquisition of China Huiyuan Juice Group Limited, finally in March 18, 2009, the Ministry of Commerce Chinese officially announced a ban on Coca-Cola to buy Huiyuan, this is the "anti-monopoly law" since the implementation of the first case has not been adopted.

\section{A Review of the Research on the Competitiveness of China's Beverage Manufacturing Industry}

So far, there are not many domestic scholars conducting researches into the competitiveness of 
the beverage manufacturing industry, both theoretically and empirically, and researches on tea, liquor, beer and wine main compare the international competitiveness.

XU Guoquan, etc. (2007) compare the gap between China's and developed countries in the international competitiveness of tea by calculating the comparative advantage index. Using Porter's "diamond model" theory, this paper analyzes the characteristics of China's tea industry from the factor endowment of China's tea, domestic demand, related industries and Industry organizations in four areas, the analysis of the reasons for the formation of a gap in competitiveness ${ }^{\text {9]. Li Daowei }}$ (2007) draws lessons from the CMS model and RCA index to analyze the comparative advantage of Chinese tea industry, and draws some conclusion that the Chinese tea industry has certain comparative advantage, but its comparative advantage is gradually decreasing [10]. Liu Yannian (2008) analyzed the advantages and disadvantages of Chinese tea in the international market and the various opportunities and threats encountered by SWOT analysis and the three indices of IMS, RCA and TC in the measurement ${ }^{[11]}$.

The world's tea exports are relatively concentrated, basically in Asia and Africa area, forming the monopoly pattern of competition between main tea production countries like China, Kenya, Sri Lanka, India and Indonesia, and tea production of these five countries accounts for over $80 \%$ of the world's total tea production. Therefore, in the analysis of international competitiveness, most domestic scholars use IMS, RCA, TC to compare and analyze these four countries. Zhang Jing (2012), Han Xiao (2013), Zhao Jie (2014) use the three the empirical analysis of the evaluation index, respectively, to assess the international competitiveness of China's tea industry. In addition to using the above three evaluation indicators, Xu Yongmei (2006) used OLP as a proxy indicator, the establishment of two models, the international competitiveness of China's tea industry, an empirical analysis of the development of China's tea industry is still in the lower intensive management Stage, tea processing enterprises have a lower level of productivity ${ }^{[12]}$. Wanqing et al. (2006) and Yan Fengzhu (2006) all used the three explicit evaluation indexes and the implicit evaluation index of IMS, RCA index and producer price index. It was pointed out that Chinese tea was basically at a disadvantage in four evaluation indexes, Especially in the RCA index, producer price index and yield of three indicators. Yan Zhenyu (2010) using IMS, RCA index, export unit price calculation to find the main advantages of Chinese tea.

There are few literatures on wine industry in international competition research. Zhang Jiaqing (2008) used IMS, TC and RCA to calculate and compare the relevant indexes of the international competitiveness of the four distilleries, and give a more complete orientation to the international competitiveness of China's liquor industry ${ }^{[13]}$. Ye Ying (2009) mainly used RCA to compare the international competitiveness of wine industry in China, France, Italy, West and Macao ${ }^{[14]}$. (2013) through the construction of the international competitiveness of the wine industry evaluation index system, combined with gray correlation and ideal solution from four levels of China and nine trade power of the wine industry international competitiveness of a comparative analysis, the results show that: China's wine industry has an advantage in terms of its competitiveness, at a disadvantage in terms of competitiveness and competitiveness, and at the forefront of its competitiveness ${ }^{[15]}$.

\section{Conclusion}

To sum up, we can analyze the current status of the beverage manufacturing industry in China and each province from the perspective of Porter's "Diamond Model", design index system related to the industry, find factors affecting the competitiveness, clarify the advantages and disadvantages of the competitiveness, analyze causes to the gap between the competitiveness and propose measures and suggestions to improve the competitiveness. This in-depth study is one that contributes to the improvement of the theoretical system of industrial competitiveness. At present, the study of industrial competitiveness has formed a very rich theoretical and empirical research results, but domestic scholars do not have a systematic study on the competitiveness of beverage manufacturing industry. Second, we hope that through the research and analysis of China and the province's beverage manufacturing industry, to develop a reasonable, scientific and feasible index system, to find the key elements to enhance the competitiveness of the industry, help to help the 
government to develop industrial policies, the establishment of an effective industrial structure , Optimize the industrial structure, rational industrial layout, improve China's beverage industry's industrial competitiveness, and promote the effective development of the economy.

\section{Acknowledgement}

"Liaoning Province, the old industrial base beverage manufacturing industry productivity research", Liaoning Provincial Education Department project (project number: WZ2016005).

\section{References}

[1] Michael E. Porter, The Competitive Advantage of Nations [J]. New York, 1990 (1). [2] Jin Bei. Research on International Competitiveness of Industry [J]. Economic Research, 1996(11): 39-45.

[2] Adam Smith, An Inquiry into the Nature and Causes of the Wealth of Nations [M], 1976.

[3] David Ricard, On the Principles of Political Economy and Taxation [M], 1817.

[4] Gottfried Von Haberler, The Theory of International Trade [M], 1936.

[5] Dunning J H: The Competitive Advantage of Countries and The Activities Of Transnational Corporations [J]. Transnational Corporations, 1993(2), 135-168.

[6] H. Chang Moon, Alan M. Rugman, Alain Verbeke. A Generalized Double Diamond Approach to The Global Competitiveness of Korea and Singapore. International Business Review [J], 1998(7), 135-150.

[7] Dong-sung Cho, Hwy-Chang Moon, From Adam Smith to Michael Porter: Evolution of Competitiveness Theory. Word Scientific, 2000.

[8] Xu Guoquan, Chen Chungen. On the Analysis of China's International Competitiveness of Tea Based on RCA and "National Diamond" Model [J]. International Trade Issues, 2007(11):38-43.

[9] Li Daohe, Gao Lan. Experimental Analysis on the International Competitiveness of China's Tea Industry [J], 2007(7):23-26.

[10]Liu Yanni. SWOT Analysis of China's Tea Industry International Competitiveness [J]. China's Collective Economy, 2008(7):29-30.

[11] Xu Yongmei. Comparative Analysis of International Competitiveness of Chinese Tea Export [J]. World Agriculture, 2006(1):26-28.

[12]Zhang Jiaqing, Liu Duruo. Chinese International Competitiveness Analysis of Chinese Liquor Industry [J]. Marketing, 2008(2):256-257.

[13] Ye Ying. Analysis of International Competitiveness of Chinese Wine Industry [J]. Journal of Jiangsu Agricultural Sciences, 2009(4):1-3.

[14]Zhang Jia-qing, Zhu Yan. Empirical Study on the International Competitiveness of China's Wine Industry [J]. Journal of International Business University (Philosophy and Social Sciences), 2013(6):31-39. 